\title{
| Constitucional. Procurador municipal. Funções essenciais à Justiça. Teto de remuneração dos procuradores municipais: art. 37, inciso XI, da Constituição: exegese
}

\author{
Carlos Mário da Silva Velloso*
}

PARECER

SUMÁRIO: I. A exposição e a consulta. II. Síntese da controvérsia. III. A Constituição Federal de 1988 e a remuneração dos servidores públicos. IV. A EC 19/1998. V. A EC 41/2003. VI. A EC 47/2005. VII. As funções essenciais à Justiça. VIII. O outro lado da moeda: os meios para assegurar o efetivo exercício das funções essenciais à Justiça. IX. Considerações sobre a Advocacia Pública. X. Análise do caso concreto. XI. Conclusão: resposta à indagação.

\footnotetext{
* Professor emérito da Universidade de Brasília (UnB), e da Pontifícia Universidade Católica de Minas Gerais (PUC-MG), em cujas Faculdades de Direito foi professor titular de direito constitucional e de teoria geral do direito público. Professor emérito da Escola da Magistratura Federal da

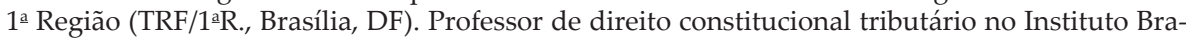
siliense de Direito Público (IDP). Doutor honoris causa pela Universidade de Craiova, Romênia, e pelo Centro Universitário da Cidade do Rio de Janeiro. Advogado: OAB/MG no 7.725; OAB/DF no 23.750 .
} 


\section{A exposição e a consulta}

1. A Associação Nacional dos Procuradores Municipais, através de sua ilustre presidente, dra. Cristiane da Costa Nery, informa existir controvérsia sobre a exata definição do limite de remuneração dos procuradores municipais, o que tem gerado litígios judiciais em alguns municípios.

1.1. Diz que, em Belo Horizonte, MG, Rio de Janeiro, RJ, Vitória, ES, Santos, SP e Porto Alegre, RS, por exemplo, as respectivas chefias do Executivo entendem que o teto de remuneração dos procuradores municipais é o montante pecuniário do subsídio do prefeito. Afirma ser equivocado esse entendimento, assinalando que a adequada inteligência do preceito constitucional que disciplina a matéria conduz, necessariamente, a esta solução: o teto de remuneração dos procuradores municipais corresponde ao subsídio fixado para os desembargadores do Tribunal de Justiça. Esse é o entendimento adotado pelos municípios de São Paulo, Fortaleza e Rio de Janeiro, por exemplo.

1.2. Nesse contexto, formula a Associação Nacional dos Procuradores Municipais a seguinte consulta:

A ressalva contida na parte final do inciso XI do art. 37 da Constituição Federal, na redação dada pela Emenda Constitucional n. 41, de 2003 - "aplicável esse limite aos membros do Ministério Público, aos Procuradores e aos Defensores Públicos" - , no que concerne "aos Procuradores", alcança os Procuradores Municipais?

\section{Síntese da controvérsia}

2. Busca-se, no caso, perquirir a correta compreensão acerca do art. 37, XI, da Carta da República, no que diz com o limite de remuneração dos procuradores municipais: se o subsídio devido ao prefeito ou ao desembargador.

2.1. De regra, apoiam-se, os que entendem que o limite de remuneração dos procuradores municipais é o subsídio do prefeito, no fato de o art. 37, XI, da Lei Maior, ter fixado esse teto para o funcionalismo local. Sustentam que a aplicabilidade do art. 37, XI, da Constituição, no que toca aos advogados públicos, está circunscrita aos procuradores estaduais e distritais, diante da remissão, ali contida, ao limite fixado para os desembargadores, não havendo, na organização administrativa municipal, cargo similar. Acrescen- 
tam que a remuneração dos procuradores municipais sujeitar-se-ia à política salarial local, entendimento, data venia, não condizente com a Constituição, dado que se embasa mais em razões financeiras, razões políticas, do que em razões jurídicas, incidindo, assim, na censura proclamada pelo Supremo Tribunal Federal, de que razões de Estado não justificam desobediência à Carta da República. ${ }^{1}$

\section{A Constituição de 1988 e a remuneração dos servidores públicos}

3. A Constituição de 1988 quis conter descalabros administrativos, particularmente no tocante aos vencimentos do funcionalismo público em geral, como resposta aos então amaldiçoados marajás.

3.1. Assim, em sua redação original, a Lei Maior impôs, no inciso XI, do art. 37, um teto de remuneração, estabelecendo que

a lei fixará o limite máximo e a relação de valores entre a maior e a menor remuneração dos servidores públicos, observados, como limites máximos e no âmbito dos respectivos Poderes, os valores percebidos como remuneração, em espécie, a qualquer título, por membros do Congresso Nacional, Ministros de Estado e Ministros do Supremo Tribunal Federal e seus correspondentes nos Estados, no Distrito Federal e nos Territórios, e, nos Municípios, os valores percebidos como remuneração, em espécie, pelo Prefeito.

\footnotetext{
1 “RAZÕES DE ESTADO NÃO PODEM SER INVOCADAS PARA LEGITIMARO DESRESPEITO À SUPREMACIA DA CONSTITUIÇÃO DA REPÚBLICA. A invocação das razões de Estado - além de deslegitimar-se como fundamento idôneo de justificação de medidas legislativas - representa, por efeito das gravíssimas consequências provocadas por seu eventual acolhimento, uma ameaça inadmissível às liberdades públicas, à supremacia da ordem constitucional e aos valores democráticos que a informam, culminando por introduzir, no sistema de direito positivo, um preocupante fator de ruptura e de desestabilização político-jurídica. Nada compensa a ruptura da ordem constitucional. Nada recompõe os gravíssimos efeitos que derivam do gesto de infidelidade ao texto da Lei Fundamental. A defesa da Constituição não se expõe, nem deve submeter-se, a qualquer juízo de oportunidade ou de conveniência, muito menos a avaliações discricionárias fundadas em razões de pragmatismo governamental. A relação do Poder e de seus agentes com a Constituição, há de ser, necessariamente, uma relação de respeito. Se, em determinado momento histórico, circunstâncias de fato ou de direito reclamarem a alteração da Constituição, em ordem a conferir-lhe um sentido de maior contemporaneidade, para ajustá-la, desse modo, às novas exigências ditadas por necessidades políticas, sociais ou econômicas, impor-se-á a prévia modificação do texto da Lei Fundamental, com estrita observância das limitações e do processo de reforma estabelecidos na própria Carta Política". (ADIn 2.010-MC/DF, ministro Celso de Mello)
} 
3.2. Esse comando foi coadjuvado pelo art. 17 do ADCT, impedindo a invocação de direitos adquiridos como óbice ao implemento da diretriz veiculada pela Constituição, realçando que

os vencimentos, a remuneração, as vantagens e os adicionais, bem como os proventos de aposentadoria que estejam sendo percebidos em desacordo com a Constituição, serão imediatamente reduzidos aos limites dela decorrentes, não se admitindo, neste caso, invocação de direito adquirido ou percepção de excesso a qualquer título.

3.3. O Supremo Tribunal, interpretando esses preceitos em conjunto com o $\S 1^{\circ}$ do art. 39 da Carta, estatuindo a isonomia de vencimentos entre cargos com atribuições iguais ou assemelhadas dos três Poderes, assentou que o teto de remuneração comportava exceções. Na ADI 14-DF, o Supremo decidiu que as vantagens pessoais e as relativas à natureza e ao local do trabalho não integravam os vencimentos dos cargos.

3.4. Registrou o relator, o eminente ministro Célio Borja, que as vantagens pessoais constituem atributo e apanágio do servidor, pelo que foi proclamada a inconstitucionalidade da Lei nำ 7.721/89, ao limitar os vencimentos dos ministros da Suprema Corte à remuneração máxima do Poder Executivo, incluídos os adicionais por tempo de serviço. Dezenas de outros pronunciamentos estratificaram essa inteligência, sendo certa a exclusão das vantagens pessoais do teto remuneratório na vigência da redação original do inciso XI do art. 37 da Carta da República.

\section{A Emenda Constitucional no 19 , de 1998}

4. Com a EC no 19/1998, que deu nova redação ao inciso XI do art. 37 estabeleceu-se que

a remuneração e o subsídio dos ocupantes de cargos, funções e empregos públicos da administração direta, autárquica e fundacional, dos membros de qualquer dos Poderes da União, dos Estados, do Distrito Federal e dos Municípios, dos detentores de mandato eletivo e dos demais agentes políticos e os proventos, pensões ou outra espécie remuneratória, percebidos cumulativamente ou não, incluídas as vantagens 
pessoais ou de qualquer outra natureza, não poderão exceder o subsídio mensal, em espécie, dos Ministros do Supremo Tribunal Federal.

\subsection{Essa Emenda acrescentou o $\S 4^{\circ}$ ao art. 39, disciplinando que}

o membro de Poder, o detentor de mandato eletivo, os Ministros de Estado e os Secretários Estaduais e Municipais serão remunerados exclusivamente por subsídio fixado em parcela única, vedado o acréscimo de qualquer gratificação, adicional, abono, prêmio, verba de representação ou outra espécie remuneratória, obedecido, em qualquer caso, o disposto no art. 37, X e XI.

4.2. A EC nº 19/1998 robusteceu esse comando em seu art. 29, estabelecendo que

os subsídios, vencimentos, remuneração, proventos de aposentadoria e pensões e quaisquer outras espécies remuneratórias adequar-se-ão, a partir da promulgação desta emenda, aos limites decorrentes da Constituição Federal, não se admitindo a percepção de excesso a qualquer título.

4.3. Harmonizando a criação do subsídio com outras prescrições, a EC n⿳o 19/1998 conferiu nova redação ao inciso XV do art. 37 da Lei Maior, estatuindo que "o subsídio e os vencimentos dos ocupantes de cargos e empregos públicos são irredutíveis, ressalvado o disposto nos incisos XI e XIV deste artigo e nos arts. 39, § 4으, 150, II, 153, III e 153, § 2으, I".

4.4. Com a EC no 19, de 1998, foi instituído teto único de remuneração, de abrangência nacional, correspondente ao subsídio mensal, em espécie, dos ministros do Supremo Tribunal Federal.

4.5. Nesse contexto, os agentes políticos, os membros de Poder e os servidores públicos não poderiam receber mais do que o subsídio dos ministros da Suprema Corte, levando-se em conta, para o cálculo do teto, vantagens pessoais e quaisquer outras parcelas, excluídas as de caráter indenizatório. Anote-se que, nos casos de percepção cumulativa de proventos e remuneração, os valores outorgados ao beneficiário seriam somados, com vistas ao limite máximo de remuneração.

4.6. Por outro lado, ao acrescentar o § 9o ao art. 37, a EC ํำ 19/1998 explicitou que esse limite se aplicava às administrações direta, autárquica e funda- 
cional, incidindo sobre as empresas públicas e sociedades de economia mista (e suas subsidiárias) que recebessem recursos para pagamento de despesas de pessoal ou custeio.

4.7. A EC no 19/1998 acrescentou ao art. 48, da Carta Política, o inciso XV, carreando ao Congresso Nacional, com a sanção presidencial, a competência para a "fixação do subsídio dos Ministros do Supremo Tribunal Federal, por lei de iniciativa conjunta dos Presidentes da República, da Câmara dos Deputados, do Senado Federal e do Supremo Tribunal Federal, observado o que dispõem os arts. 39, § 4º, 150 , II, 153, III e 153, § 2o, I".

4.8. Presentes essas balizas, o Supremo Tribunal, na sessão administrativa de 24 de junho de 1998, entendeu não ser autoaplicável o novo limite delineado na EC no 19/1998, pois “a fixação de subsídio mensal, em espécie, de Ministro do Supremo Tribunal Federal - que servirá de teto - nos termos do art. 48, XV, da Constituição, na redação do art. 7o da referida Emenda Constitucional no 19 , depende de lei formal".

4.9. Essa exegese foi reafirmada no julgamento da liminar na ADI 1.898$\mathrm{DF}^{2}$ decidindo a Corte que não poderia o Conselho da Justiça Federal fixar as tabelas de remuneração dos magistrados, por ato normativo, antes da definição do subsídio dos ministros do Supremo Tribunal, mediante a edição de lei formal, entendimento enfatizado em outras ocasiões. ${ }^{3} \mathrm{Na}$ prática, isso significou a manutenção, enquanto não editada lei, de iniciativa quádrupla, fixando o subsídio dos ministros do Supremo Tribunal, da inteligência de que as vantagens pessoais não se incluíam no teto de remuneração. Assim, deu-se a temporária ineficácia das alterações trazidas pela EC no $19 / 1998$, eis que as vantagens pessoais incorporadas ao patrimônio do servidor continuaram imunes ao teto.

4.10. A EC no 19/1998, ao cabo, conferiu nova redação ao art. 135 da Constituição, estabelecendo que os integrantes da Advocacia-Geral da União, os procuradores dos estados e do Distrito Federal e os defensores públicos serão remunerados exclusivamente por subsídio.

\section{A Emenda Constitucional no 41, de 2003}

5. Em 2003, foi promulgada a EC no 41, conferindo a seguinte redação ao inciso XI, do art. 37, da Constituição:

\footnotetext{
${ }^{2}$ ADIn 1.898-MC/DF, ministro Octávio Gallotti.

${ }^{3}$ ADIn 2.087/AM, ministro Sepúlveda Pertence e ADIn 2.075-MC/RJ, ministro Celso de Mello, entre outros precedentes.
} 
A remuneração e o subsídio dos ocupantes de cargos, funções e empregos públicos da administração direta, autárquica e fundacional, dos membros de qualquer dos Poderes da União, dos Estados, do Distrito Federal e dos Municípios, dos detentores de mandato eletivo e dos demais agentes políticos e os proventos, pensões ou outra espécie remuneratória, percebidos cumulativamente ou não, incluídas as vantagens pessoais ou de qualquer outra natureza, não poderão exceder o subsídio mensal, em espécie, dos Ministros do Supremo Tribunal Federal, aplicando-se como limite, nos Municípios, o subsídio do Prefeito, e nos Estados e no Distrito Federal, o subsídio mensal do Governador no âmbito do Poder Executivo, o subsídio dos Deputados Estaduais e Distritais no âmbito do Poder Legislativo e o subsídio dos Desembargadores do Tribunal de Justiça, limitado a noventa inteiros e vinte e cinco centésimos por cento do subsídio mensal, em espécie, dos Ministros do Supremo Tribunal Federal, no âmbito do Poder Judiciário, aplicável esse limite aos membros do Ministério Público, aos Procuradores e aos Defensores Públicos.

5.1. Para a imediata concreção desse limite, a EC no $41 / 2003$ alterou a redação do inciso XV, do art. 48, não mais aludindo à edição de lei formal, de iniciativa quádrupla, anteriormente considerada como pressuposto para a sua eficácia. Ademais, com o visível intuito de fazer valer, sem delongas, esse teto para o funcionalismo público, abrangendo vantagens pessoais e vantagens de outras índoles, estabeleceu a citada EC no 41/2003, respectivamente, em seus arts. $8^{\circ}$ e $9^{\circ}$ :

Art. 8 Até que seja fixado o valor do subsídio de que trata o art. 37, XI, da Constituição Federal, será considerado, para os fins do limite fixado naquele inciso, o valor da maior remuneração atribuída por lei na data de publicação desta Emenda a Ministro do Supremo Tribunal Federal, a título de vencimento, de representação mensal e da parcela recebida em razão de tempo de serviço, aplicando-se como limite, nos Municípios, o subsídio do Prefeito, e nos Estados e no Distrito Federal, o subsídio mensal do Governador no âmbito do Poder Executivo, o subsídio dos Deputados Estaduais e Distritais no âmbito do Poder Legislativo e o subsídio dos Desembargadores do Tribunal de Justiça, limitado a noventa inteiros e vinte e cinco centésimos por cento da maior remuneração mensal de Ministro do Supremo Tribunal Federal a que 
se refere este artigo, no âmbito do Poder Judiciário, aplicável este limite aos membros do Ministério Público, aos Procuradores e aos Defensores Públicos.

Art. 9o Aplica-se o disposto no art. 17 do Ato das Disposições Constitucionais Transitórias aos vencimentos, remunerações e subsídios dos ocupantes de cargos, funções e empregos públicos da administração direta, autárquica e fundacional, dos membros de qualquer dos Poderes da União, dos Estados, do Distrito Federal e dos Municípios, dos detentores de mandato eletivo e dos demais agentes políticos e os proventos, pensões ou outra espécie remuneratória percebidos cumulativamente ou não, incluídas as vantagens pessoais ou de qualquer outra natureza.

5.2. Nesse contexto, 15 anos após a promulgação da Constituição de 1988, obteve-se a demarcação dos limites de remuneração, englobando vantagens pessoais: (a) nacional, o subsídio de ministro do Supremo Tribunal; (b) federal, o subsídio da mesma autoridade; (c) estadual e distrital, subdividido entre Executivo, o subsídio do governador, Legislativo, o subsídio dos deputados e Judiciário, o subsídio dos desembargadores; e, (d) municipal, o subsídio do prefeito.

5.3. Anote-se, que a EC no $41 / 2003$ criou um específico limite de remuneração para as carreiras reputadas "essenciais à Justiça", estabelecendo que os membros do Ministério Público, os procuradores e os defensores públicos não podem perceber montante pecuniário superior ao subsídio dos desembargadores.

5.4. Registre-se que, por força da EC no 41/2003, a Suprema Corte apreciou mandado de segurança ${ }^{4}$ impetrado contra a imediata redução de proventos de ministros aposentados, diante da limitação, imposta pelo subsídio, ao adicional por tempo de serviço e ao acréscimo de $20 \%$ sobre os proventos de aposentadoria. Decidiu-se que o adicional por tempo de serviço não se encontra imune à fronteira imposta pela EC no 41/2003. No tocante ao acréscimo de $20 \%$ sobre os proventos de aposentadoria, assegurada a continuidade de sua percepção até futura absorção pelos novos valores dos subsídios, dada a irredutibilidade de vencimentos atribuída aos magistrados.

5.5. Embora haja quem discorde do entendimento da Suprema Corte, certo é que essa inteligência vem sendo reiteradamente perfilhada, logrando-se

${ }^{4}$ MS 24.875-DF, ministro Sepúlveda Pertence. 
obter um efetivo teto de remuneração, eis que o regime de subsídio resultou, de fato, na absorção das vantagens pessoais.

\section{A Emenda Constitucional n ㄱ, de 2005}

6. Finalmente, a EC no 47/2005 acrescentou ao art. 37, da Constituição, os $\S \S 11$ e 12, dispondo não serem computadas, para o cálculo do limite de remuneração, "as parcelas de caráter indenizatório previstas em lei", facultando, por outro lado,

aos Estados e ao Distrito Federal fixar, em seu âmbito, mediante emenda às respectivas Constituições e lei Orgânica, como limite único, o subsídio mensal dos Desembargadores do respectivo Tribunal de Justiça, limitado a noventa inteiros e vinte e cinco centésimos por cento do subsídio mensal dos Ministros do Supremo Tribunal Federal,

estatuindo-se, todavia, que esse limite único se aplicaria "aos subsídios dos Deputados Estaduais e dos Vereadores".

6.1. Nestes termos, na atual quadra, a Constituição nos oferece seis limites de remuneração, englobando vantagens pessoais, excluídas parcelas de caráter indenizatório: ${ }^{5}$

(a) nacional, o subsídio de ministro do Supremo Tribunal;

(b) federal, o subsídio da mesma autoridade;

(c) estadual e distrital, subdivido entre o Executivo, o subsídio do governador, o Legislativo, o subsídio dos deputados e o Judiciário, o subsídio dos desembargadores;

(d) estadual e distrital, em valor único, o subsídio dos desembargadores, pressupondo emenda às Constituições e à Lei Orgânica, não alcançando, entretanto, deputados estaduais e vereadores;

(e) municipal, o subsídio do prefeito;

(f) funções essenciais à Justiça, o subsídio dos desembargadores.

6.2. Nesse passo, é necessário entender a motivação que conduziu o legislador constituinte a dispensar especial tratamento remuneratório aos integrantes das carreiras reputadas essenciais à Justiça.

\footnotetext{
${ }^{5}$ Propositadamente, deixo de aludir aos seis limites dos subsídios dos vereadores, estabelecidos em função do número de habitantes da edilidade (CF, art. 29, VI, alíneas a, b, c, d, e, f).
} 


\section{As funções essenciais à Justiça}

7. A Constituição de 1988 disciplinou a Organização dos Poderes (Título IV), indicando o Legislativo (Capítulo I - arts. 44/75), o Executivo (Capítulo II — arts. 76/91) e o Judiciário (Capítulo III — arts. 92/126). E, inovando, foi além, inserindo, na estrutura orgânica do Poder Judiciário (Capítulo IV arts. 127/135), as "Funções Essenciais à Justiça", compreendendo o Ministério Público (arts. 127/130-A), a Advocacia Pública (arts. 131/132), a Advocacia e a Defensoria Pública (arts. 133/135).

7.1. As carreiras que desempenham funções essenciais à Justiça não consubstanciam um poder, ou, como se costuma apregoar, um "Quarto Poder", embora haja quem sustente o oposto.

7.2. Ademais, a Lei Maior resolveu deferir especial tratamento ao Ministério Público, à Advocacia Pública, à Advocacia e à Defensoria Pública, dentro da disciplina constitucional relativa à organização dos poderes, colocando-os ao lado do Legislativo, do Executivo e do Judiciário. Qual a razão de ser dessa inovadora opção do legislador constituinte? Por que elevar determinadas categorias à privilegiada condição de "essenciais à Justiça"?

7.3. A resposta não pode vincular-se ao fato de os membros do Ministério Público, os advogados públicos e privados e os defensores públicos ostentarem o privativo direito de postular, isto é, a exclusiva prerrogativa de provocar o Judiciário para que ponha fim a um litígio, pronunciando o direito. Essas funções não seriam consideradas essenciais apenas pela possibilidade de se dar início a uma ação penal ou a um processo cível. Mesmo antes da Constituição de 1988, esse era o quadro. Do mesmo modo, a essencialidade do Ministério Público, dos advogados públicos e privados e dos defensores não decorre da circunstância de o Judiciário, instado por estes, intervir para reparar ilegalidades cometidas pelo Executivo ou pelo Legislativo. Essa era a moldura anterior à Constituição de 1988. E tais funções não eram consideradas funções essenciais. É dizer: Essas funções não seriam consideradas essenciais somente por possuírem os seus agentes capacidade postulatória perante o Judiciário.

7.4. Admito que esses motivos possam ser considerados necessários para a aferição da essencialidade dessas funções. Porém, não são suficientes para caracterizá-la. Penso que a inovadora opção do legislador constituinte decorreu da constatação de que o Ministério Público, a Advocacia Pública, a Advocacia e a Defensoria Pública desempenham funções essenciais ao estado 
democrático de direito em que se constitui a República Federativa do Brasil (C.F., art. $1^{\mathrm{o}}$ ).

7.5. É dizer: o Ministério Público, a Advocacia Pública, a Advocacia e a Defensoria Pública revelam-se instrumentos fundamentais e indispensáveis, (por isso, essenciais), para assegurar, cada qual com o seu trabalho, toda a gama de interesses que permeiam a Constituição, seus valores e princípios, em especial a construção de uma sociedade livre, justa e solidária $(C F$, art. 3ㅜ, I), objetivo do estado democrático de direito. Nas palavras de Diogo de Figueiredo Moreira Neto, a nova postura constitucional persegue a plena realização da Justiça, "entendida como a suma de todos os valores éticos que possibilitam e dignificam a convivência em sociedade: a licitude, a legitimidade e a legalidade". 6

7.6. Para o eminente jurista, a Carta da República incorporou duas notáveis conquistas do direito político contemporâneo: "o sistema de participação política, ampliado e enriquecido, e o sistema de funções essenciais à Justiça, aperfeiçoado e robustecido com garantias para uma atuação independente", convergindo ambos os sistemas para assegurar, "cada um com seus mecanismos, o primado da ordem jurídica, abrangente da legalidade, da legitimidade e da licitude". ${ }^{7}$ Acentuando que, diante da pluralização de interesses, reflexo jurídico da diversificação das fontes e das sedes de poder, controvérsias envolvendo a moralidade, a legitimidade e a legalidade necessitam de apresentação eficaz, externada em roupagem técnica, afirma que

o exercício de funções preventivas (consultoria jurídica) e postulatórias (representação), que não apresentem um mínimo da necessária consistência técnica, inviabiliza o controle de juridicidade (moralidade, legitimidade e legalidade) e atenta contra os fundamentos constitucionais do estado (de justiça) democrático de direito.

Resulta, então, constituírem as funções essenciais à Justiça um "conjunto de atividades políticas preventivas e postulatórias através das quais interesses juridicamente reconhecidos são identificados, acautelados, promovidos e defendidos por órgãos tecnicamente habilitados, sob garantias constitucionais". 8

\footnotetext{
${ }^{6}$ MOREIRA NETO, Diogo de Figueiredo. As funções essenciais à Justiça e as procuraturas constitucionais. Revista de Informação Legislativa, Brasília, ano 29, v. 116, p. 82, out./dez. 1992.

${ }^{7}$ Ibid., p. 81-82.

${ }^{8}$ Ibid., p. 87.
} 
7.7. Na mesma linha, Sérgio de Andréa Ferreira, a sustentar que a Constituição teve em mira "a realização da justiça, tomado esse termo não apenas no sentido de justiça de estrita legalidade; de justiça jurisdicional, mas da justiça abrangente da equidade, da legitimidade, da moralidade", estimando consolidada uma "quarta função política", ao lado das funções legislativa, executiva e judicial: "a função de provedoria de justiça". Em suas palavras:"

Outro ponto básico é que, se nos Poderes Públicos "lato sensu", situamse, agora, esse conjunto de instituições que exercem "funções essenciais à justiça", é que, respeitadas as espécies funcionais atribuídas a cada uma delas (defesa, consultoria, velamento, representação, orientação, assessoramento), se tem de identificar o gênero funcional comum, que veio a constituir-se na quarta função política, ao lado da função legislativa, da executiva e da jurisdicional: a função de provedoria de justiça, cuja finalidade é contribuir para a realização humana, democrática, equânime, do direito, seja pelo Poder Público, seja no relacionamento dos governados.

7.8. Corroborando o entendimento doutrinário de que a essencialidade do Ministério Público, da Advocacia Pública, da Advocacia e Defensoria Pública decorre da guarda dos mais variados interesses do estado democrático de direito, essa significativa decisão, tocante à Defensoria Pública, do Supremo Tribunal Federal: ${ }^{10}$

A Defensoria Pública, enquanto instituição permanente, essencial à função jurisdicional do Estado, qualifica-se como instrumento de concretização dos direitos e das liberdades de que são titulares as pessoas carentes e necessitadas. É por essa razão que a Defensoria Pública não pode (e não deve) ser tratada de modo inconsequente pelo Poder Público, pois a proteção jurisdicional de milhões de pessoas - carentes e desassistidas - , que sofrem inaceitável processo de exclusão jurídica e social, depende da adequada organização e da efetiva institucionalização desse órgão do Estado.

\footnotetext{
${ }^{9}$ FERREIRA, Sérgio de Andréa. Comentários à Constituição. Rio de Janeiro: Freitas Bastos, 1991. v. 3, p. 12-13.

${ }^{10}$ ADIn 2.903-PB, ministro Celso de Mello.
} 
De nada valerão os direitos e de nenhum significado revestir-se-ão as liberdades, se os fundamentos em que eles se apoiam - além de desrespeitados pelo Poder Público ou transgredidos por particulares - também deixarem de contar com o suporte e o apoio de um aparato institucional, como aquele proporcionado pela Defensoria Pública, cuja função precípua, por efeito de sua própria vocação constitucional (CF, art. 134), consiste em dar efetividade e expressão concreta, inclusive mediante acesso do lesado à jurisdição do Estado, a esses mesmos direitos, quando titularizados por pessoas necessitadas, que são as reais destinatárias tanto da norma inscrita no art. 5ㅜ, inciso LXXIV, quanto do preceito consubstanciado no art. 134, ambos da Constituição da República.

7.9. Do erudito voto do eminente ministro Celso de Mello, extraio excerto que confirma a assertiva de que nos deparamos com função essencial para a configuração e subsistência do estado democrático de direito:

É preciso reconhecer, desse modo, que assiste, a toda e qualquer pessoa - especialmente quando se tratar daquelas que nada têm e que de tudo necessitam - , uma prerrogativa básica que se qualifica como fator de viabilização dos demais direitos e liberdades.

Torna-se imperioso proclamar, por isso mesmo, que toda pessoa tem direito a ter direitos, assistindo-lhe, nesse contexto, a prerrogativa de ver tais direitos efetivamente implementados em seu benefício, o que põe em evidência - cuidando-se de pessoas necessitadas ( $\mathrm{CF}$, art. 50 LXXIV) - a significativa importância jurídico-institucional e políticosocial da Defensoria Pública.

É que, Senhor Presidente, sem se reconhecer a realidade de que a Constituição impõe, ao Estado, o dever de atribuir aos desprivilegiados - verdadeiros marginais do sistema jurídico nacional - a condição essencial de titulares do direito de serem reconhecidos como pessoas investidas de dignidade e merecedoras do respeito social, não se tornará possível construir a igualdade, nem realizar a edificação de uma sociedade justa, fraterna e solidária, frustrando-se, assim, um dos objetivos fundamentais da República (CF, art. 3o, I).

Vê-se, portanto, de um lado, a enorme relevância da Defensoria Pública, enquanto Instituição permanente da República e organismo essencial à função jurisdicional do Estado, e, de outro, o papel de grande respon- 
sabilidade do Defensor Público, em sua condição de agente incumbido de viabilizar o acesso dos necessitados à ordem jurídica justa, capaz de propiciar-lhes, mediante adequado patrocínio técnico, o gozo - pleno e efetivo - de seus direitos, superando-se, desse modo, a situação de injusta desigualdade socioeconômica a que se acham lamentavelmente expostos largos segmentos de nossa sociedade. ${ }^{11}$

7.10. Nesse contexto, pode-se concluir que a inovadora opção constitucional, alçando agentes públicos à condição de "essenciais à Justiça", decorre da inegável circunstância de o Ministério Público, a Advocacia Pública, a Advocacia e a Defensoria Pública representarem instrumentos fundamentais à efetiva consecução dos valores e princípios que permeiam a Constituição. Sejam advogados da sociedade (Ministério Público), do Estado (advogados da União e procuradores das unidades federadas), dos hipossuficientes (Defensoria Pública) ou advogados privados, certo é que todos contribuem para a concretização da dimensão igualitária da Justiça.

\section{O outro lado da moeda: os meios para assegurar o efetivo exercício das funções essenciais à Justiça}

8. Se a essa constatação não se pode opor fundada contrariedade, porque, de fato, o legislador constituinte objetivou proteger relevantes interesses do estado democrático de direito, certo é que, em consequência, haverá de fornecer os meios necessários para tanto. Esse o outro lado da moeda: a Carta da República, coerente com seus ideais, há de viabilizar o efetivo exercício das funções essenciais à Justiça, mediante o oferecimento de garantias que ensejem atuação imune a ingerências ou pressões.

\footnotetext{
${ }^{11}$ Ainda sobre essencialidade da Defensoria Pública, consulte-se a decisão proferida na ADIn 3.700-RN (ministro Carlos Britto), rechaçando a possibilidade de sua composição em caráter precário, inexistindo cargos de provimento efetivo e prévio concurso público, comprometendo sua independência técnica: "1. A Defensoria Pública se revela como instrumento de democratização do acesso às instâncias judiciárias, de modo a efetivar o valor constitucional da universalização da justiça (inciso XXXV do art. 5o da CF/88). 2. Por desempenhar, com exclusividade, um mister estatal genuíno e essencial à jurisdição, a Defensoria Pública não convive com a possibilidade de que seus agentes sejam recrutados em caráter precário. Urge estruturá-la em cargos de provimento efetivo e, mais que isso, cargos de carreira. 3. A estruturação da Defensoria Pública em cargos de carreira, providos mediante concurso público de provas e títulos, opera como garantia da independência técnica da instituição, a se refletir na boa qualidade da assistência a que fazem jus os estratos mais economicamente débeis da coletividade. 4. Ação direta julgada procedente".
} 
8.1. José Afonso da Silva, ao discorrer sobre a institucionalização da Advocacia Pública," resultante dos "novos reclamos da sociedade em transformação", afirma ser indispensável assegurar "a estabilidade de funções e dos vencimentos", invocando antiga lição de Francisco Campos, nos seguintes termos:

Toda vez que um serviço, por conveniência pública, é erigido em instituição autônoma, com capacidade própria de decisão, ou com a capacidade de decidir mediante juízos ou critérios da sua própria escolha, excluída a obrigação de observar ordens, instruções, injunções ou avisos de autoridades estranhas ao quadro institucional, com o fito de evitar infiltrações de natureza política no exercício da sua competência deliberativa ou decisória, impõe-se a garantia aos funcionários incumbidos de tomar as deliberações ou decisões institucionais, da necessária independência, mediante a única técnica eficaz, empregada em relação à Justiça, de lhes assegurar a estabilidade nas funções e nos soldos.

8.2. A Constituição Federal não se descuidou desse sensível aspecto. Ao incumbir o Ministério Público da defesa da ordem jurídica, do regime democrático e dos interesses sociais e individuais indisponíveis, assegurou-lhe unidade, indivisibilidade, independência funcional, autonomia funcional e administrativa, vitaliciedade, inamovibilidade e irredutibilidade de subsídio. Com isso, ensejou o desempenho de suas atribuições, entre elas (a) promover, privativamente, a ação penal pública, (b) zelar pelo efetivo respeito dos poderes públicos e dos serviços de relevância pública aos direitos assegurados na Constituição, promovendo as medidas necessárias à sua garantia, (c) promover o inquérito civil e a ação civil pública, para a proteção do patrimônio público e social, do meio ambiente e de outros interesses difusos e coletivos, (d) propor ação de inconstitucionalidade ou representação para fins de intervenção da União e dos estados, (e) defender judicialmente os direitos e os interesses das populações indígenas, e (g) exercer o controle externo da atividade policial.

8.3. Da mesma forma, ao incumbir a Defensoria Pública da orientação jurídica e a defesa, em todos os graus, dos necessitados, garantiu-lhe autonomia funcional e administrativa, conferindo inamovibilidade aos seus membros.

12 SILVA, José Afonso da. Comentário contextual à Constituição. 5. ed. São Paulo: Malheiros, 2008. p. 605. 
8.4. Aos advogados da União atribuiu-se a representação judicial e extrajudicial e as atividades de consultoria e assessoramento jurídico do Poder Executivo. Aos procuradores dos estados e aos procuradores do Distrito Federal, por sua vez, outorgou-se a representação judicial e a consultoria jurídica das respectivas unidades federadas. Em contrapartida, a todos os integrantes da Advocacia Pública, assegurou-se estabilidade, irredutibilidade de subsídio e inviolabilidade profissional, além de a Constituição impor o ingresso nas respectivas carreiras mediante concurso público de provas e títulos.

8.5. Relativamente à advocacia privada, indispensável à administração da Justiça, estabeleceu a Constituição ser o advogado inviolável, nos limites da lei, por seus atos e manifestações no exercício da profissão, garantindo, assim, o pleno exercício dos seus encargos. Não é demasia registrar, no ponto, a evidenciar a independência inerente aos causídicos no desempenho de suas essenciais funções, que o Supremo Tribunal Federal, no julgamento da ADI 3.026-DF, ${ }^{13}$ assentou que a Ordem dos Advogados do Brasil: (a) não se sujeita aos ditames impostos à administração pública direta e indireta; (b) não é entidade da administração indireta da União, tampouco incluída na categoria das autarquias especiais, caracterizando serviço público independente (categoria ímpar no elenco das personalidades jurídicas); (c) não está sujeita a qualquer controle da administração, nem vinculada a qualquer das suas partes, não possuindo relação de dependência com qualquer órgão público, e, (d) não é congênere dos demais órgãos de fiscalização profissional. Autônoma e independente, a OAB não se limita a objetivos corporativos, ostentando finalidade institucional. ${ }^{14}$

\footnotetext{
${ }^{13}$ ADIn 3.026-DF, ministro Eros Grau.

${ }^{14}$ Também o Superior Tribunal de Justiça teve a oportunidade de enaltecer as finalidades institucionais da Ordem dos Advogados do Brasil: "MANDADO DE SEGURANÇA. MINISTÉRIO DA EDUCAÇÃO. PORTARIA. AUMENTO NO NÚMERO DE VAGAS DOS CURSOS JURÍDICOS SEM PRÉVIA MANIFESTAÇÃO DA OAB. IMPOSSIBILIDADE. DESCUMPRIMENTO DE REQUISITO FORMAL PARA A PRÁTICA DO ATO ADMINISTRATIVO. RELEVÂNCIA CONSTITUCIONAL DA PROFISSÃO DE ADVOGADO E DEMAIS CARREIRAS JURÍDICAS. A educação pode e deve ser prestada pela sociedade civil, mas sempre sob a supervisão do Estado, para a garantia da qualidade do ensino, nos termos das normas gerais da educação nacional. Ao Estado, contudo, não é lícito fixar tais normas a seu bel-prazer, seja desrespeitando os direitos dos particulares que se dedicam ao ensino, seja em desrespeito à qualidade da educação exigida pela própria Constituição Federal. Primeiro o Estatuto da OAB e depois o Decreto n. 3.860/2001, que regulamentou a Lei de Diretrizes e Bases da Educação Nacional, Lei n. 9.39496, preveem expressamente que ao Conselho Federal da Ordem dos Advogados do Brasil compete se manifestar nos pedidos de criação e reconhecimento de qualquer curso jurídico em instituições de ensino superior. A comparação entre o número de vagas e a infraestrutura oferecida pela instituição é fundamental para a verificação da qualidade de qualquer curso. Compete à $\mathrm{OAB}$ a aferição da capacidade para o exercício profissional da advocacia, atribuição que lhe é conferida pelo artigo
} 
8.6. Está-se a ver que a Constituição conferiu aos integrantes do Ministério Público, da Advocacia Pública, da Advocacia e da Defensoria Pública, salvaguardas básicas para o efetivo exercício de suas funções, procurando garantir atuação imune a pressões ou ingerências políticas ou econômicas.

\section{A Advocacia Pública}

9. A Carta da República outorgou aos advogados públicos a representação judicial e a consultoria jurídica das unidades federadas a que se vinculam. Porque desempenham "funções essenciais à Justiça", isto é, atividades direcionadas à realização dos valores e princípios inscritos na Constituição, com vistas à concretização do estado democrático de direito, os advogados públicos não se limitam a acautelar os exclusivos interesses patrimoniais das unidades federadas.

9.1. Ao contrário, defendem o interesse público, assim entendido, consoante o magistério de Celso Antônio Bandeira de Mello, ${ }^{15}$ como "interesse resultante do conjunto dos interesses que os indivíduos pessoalmente têm quando considerados em sua qualidade de membros da sociedade e pelo simples fato de o serem", distinguindo-se interesses públicos "primários e secundários":

43. Outrossim, a noção de interesse público, tal como a expusemos, impede que se incida no equívoco muito grave de supor que o interesse público é exclusivamente um interesse do Estado, engano, este, que faz resvalar fácil e naturalmente para a concepção simplista e perigosa de identificá-lo com quaisquer interesses da entidade que representa o todo (isto é, o Estado e demais pessoas de Direito Público interno).

Uma vez reconhecido que os interesses públicos correspondem à dimensão pública dos interesses individuais, ou seja, que consistem no plexo dos interesses dos indivíduos enquanto partícipes da sociedade

\footnotetext{
8o, inciso I, da Lei n. 8.906/94, o que, por si só, é mister de indisfarçável cunho cívico e social, a justificar, per se, a razão de sua ouvida, em processos que tais. O poder do Ministério da Educação não é soberano para exercer as atribuições do Poder Público Federal em matéria de educação, visto que, pelo menos no que tange ao curso de direito - requisito indispensável para o exercício de todas as funções essenciais à Justiça -, está o Poder Público vinculado, para edição de atos normativos, não somente à Lei, mas à própria Constituição. Mandado de segurança concedido" (MS 8.219-DF, ministro Franciulli Netto).

${ }^{15}$ BANDEIRA DE MELLO, Celso Antônio. Curso de direito administrativo. 27. ed. São Paulo: Malheiros, 2010. p. 62 e 65-66.
} 
(entificada juridicamente no Estado), nisto incluído o depósito intertemporal destes mesmos interesses, põe-se a nu a circunstância de que não existe coincidência necessária entre interesse público e interesse do Estado e demais pessoas de Direito Público.

44. É que, além de subjetivar estes interesses, o Estado, tal como os demais particulares, é, também ele, uma pessoa jurídica, que, pois, existe e convive no universo jurídico em concorrência com todos os demais sujeitos de direito. Assim, independentemente do fato de ser, por definição, encarregado dos interesses públicos, o Estado pode ter, tanto quanto as demais pessoas, interesses que lhe são particulares, individuais, e que, tal como os interesses delas, concebidas em suas meras individualidades, se encarnam no Estado enquanto pessoa. Estes últimos não são interesses públicos, mas interesses individuais do Estado, similares, pois (sob prisma extrajurídico), aos interesses de qualquer outro sujeito. Similares, mas não iguais. Isto porque a generalidade de tais sujeitos pode defender estes interesses individuais, ao passo que o Estado, concebido que é para a realização de interesses públicos (situação, pois, inteiramente diversa da dos particulares), só poderá defender seus próprios interesses privados quando, sobre não se chocarem com os interesses públicos propriamente ditos, coincidam com a realização deles. Tal situação ocorrerá sempre que a norma donde defluem os qualifiquem como instrumentais ao interesse público e na medida em que o sejam, caso em que sua defesa será, ipso facto, simultaneamente a defesa de interesses públicos, por concorrerem indissociavelmente para a satisfação deles.

45. Esta distinção a que se acaba de aludir, entre interesses públicos propriamente ditos - isto é, interesses primários do Estado - e interesses secundários (que são os últimos a que se aludiu), é de trânsito corrente e moente na doutrina italiana, e a um ponto tal que hoje, poucos doutrinadores daquele país se ocupam em explicá-los, limitando-se a fazer-lhes menção, como referência a algo óbvio, de conhecimento geral. Este discrímen, contudo, é exposto com exemplar clareza por Renato Alessi, colacionando lições de Carnelutti e Picardi, ao elucidar que os interesses secundários do Estado só podem ser por ele buscados quando coincidentes com os interesses primários, isto é, com os interesses públicos propriamente ditos.

9.2. Os advogados do Estado, portanto, no desempenho de suas funções, ligadas à representação judicial ou à consultoria jurídica, devem ter presente 
que não se submetem à vontade dos governantes. Submetem-se, sim, à Constituição e às leis.

9.3. Certo que a administração é um mero veículo da vontade estatal consagrada em lei e que um bem público "não se entende vinculado à vontade ou personalidade do administrador, porém à finalidade impessoal a que essa vontade deve servir", ${ }^{16}$ os advogados públicos devem pautar sua atuação na observância, sobretudo, dos princípios da legalidade, da moralidade administrativa e da impessoalidade, sopesando e ponderando interesses contrapostos, apontando, sempre, eventuais ilicitudes perpetradas pelos administradores, interditando o possível cometimento de outras, seja em sua atuação judicial, seja em sua atuação consultiva.

9.4. A Lei Maior preocupou-se em conferir aos integrantes da Advocacia Pública a prerrogativa de evitar a prática de eventuais ofensas à legalidade, mediante antecedente exame dos atos administrativos, resguardando o interesse público. Daí que o exame da legalidade dos atos administrativos, ou o controle jurídico preventivo da administração, há de ser realizado por servidores efetivos, estáveis, preparados, integrantes de corpo técnico especializado, admitidos por concurso público e organizados em carreira. Só assim pode o procurador dizer que atos do governador ou do secretário de Estado não se amoldam à lei, sem que, por isso, sinta-se amedrontado diante de eventuais represálias da autoridade contrariada, o que, evidentemente, não ocorre com ocupante de cargos sem tais garantias.

9.5. No particular, lúcidas as observações de Diogo de Figueiredo Moreira Neto, ao anotar que

a consultoria jurídica é atividade essencial à justiça, porquanto nela o advogado tem a decisão técnico-jurídica a seu cargo e sob sua plena responsabilidade, direta e pessoal. O consultor jurídico do Poder Público emite uma vontade estatal, como órgão do Estado que é, vinculandoo de tal forma que, se a Administração não seguir o ditame, deverá motivar porque não o faz, sob pena de nulidade do ato (princípio da motivação - artigo 5, LIV e LV e 93, X),

arrematando: ${ }^{17}$

${ }^{16}$ CIRNE LIMA, Rui. Princípios de direito administrativo. 7. ed. São Paulo: Malheiros, 2007. p. 37.

${ }^{17}$ MOREIRA NETO, op. cit., p. 89. 
Seus pronunciamentos têm, por isso, uma eficácia própria, que é a eficácia do parecer jurídico, indistintamente os emitidos por solicitação externa ou ex officio, no exercício de funções de fiscalização da juridicidade dos atos do Estado, embora possam alguns pender de um visto ou qualquer outro ato de assentimento para cobrarem exequibilidade. Os órgãos da Administração Pública, que têm na ordem jurídica não só o fundamento como os limites de sua atuação, não podem ignorar os pareceres regularmente emitidos pelas consultorias jurídicas dos órgãos da procuratura constitucional que sobre elas atuem, embora possam deixar de segui-los, motivadamente, mas sempre a seu inteiro risco, jurídico e político.

9.6. Diferenciando consultas facultativas e obrigatórias, passíveis de serem endereçadas aos advogados públicos por autoridades administrativas, decidiu o Supremo Tribunal Federal, ${ }^{18}$ endossando, em parte, a doutrina de Diogo de Figueiredo Moreira Neto:

CONTROLE EXTERNO. AUDITORIA PELO TCU. RESPONSABILIDADE DE PROCURADOR DE AUTARQUIA POR EMISSÃO DE PARECER TÉCNICO-JURÍDICO DE NATUREZA OPINATIVA. SEGURANÇA DEFERIDA.

I. Repercussões da natureza jurídico-administrativa do parecer jurídico: (i) quando a consulta é facultativa, a autoridade não se vincula ao parecer proferido, sendo que seu poder de decisão não se altera pela manifestação do órgão consultivo; (ii) quando a consulta é obrigatória, a autoridade administrativa se vincula a emitir o ato tal como submetido à consultoria, com parecer favorável ou contrário, e se pretender praticar ato de forma diversa da apresentada à consultoria, deverá submetê-lo a novo parecer; (iii) quando a lei estabelece a obrigação de decidir à luz de parecer vinculante, essa manifestação de teor jurídico deixa de ser meramente opinativa e o administrador não poderá decidir senão nos termos da conclusão do parecer ou, então, não decidir.

\footnotetext{
${ }^{18}$ MS 24.631-DF, ministro Joaquim Barbosa. José Vicente Santos de Mendonça disserta a respeito da responsabilidade pessoal do parecerista público a partir de quatro standards construídos pelo Supremo Tribunal Federal nos MMSS 24.073-DF, ministro Carlos Velloso, 24.584-DF, ministro Marco Aurélio e 24.631-DF, ministro Joaquim Barbosa. MENDONÇA, José Vicente Santos de. A responsabilidade pessoal do parecerista público em quatro standards. Boletim de Direito Administrativo, v. 6, n. 26, p. 705, jun. 2010.
} 
II. No caso de que cuidam os autos, o parecer emitido pelo impetrante não tinha caráter vinculante. Sua aprovação pelo superior hierárquico não desvirtua sua natureza opinativa, nem o torna parte de ato administrativo posterior do qual possa eventualmente decorrer dano ao erário, mas apenas incorpora sua fundamentação ao ato.

III. Controle externo: é lícito concluir que é abusiva a responsabilização do parecerista à luz de uma alargada relação de causalidade entre seu parecer e o ato administrativo do qual tenha resultado dano ao erário. Salvo demonstração de culpa ou erro grosseiro, submetida às instâncias administrativo-disciplinares ou jurisdicionais próprias, não cabe a responsabilização do advogado público pelo conteúdo de seu parecer de natureza meramente opinativa.

Mandado de segurança deferido.

9.7. No sentido do exposto, encarecendo a primordial função de contribuir para o aperfeiçoamento do estado democrático de direito, José Afonso da Silva realça que a Advocacia Pública

não tem a função estrita de defesa dos interesses da Fazenda Pública em juízo. Nem é defensora dos interesses do governante do dia, nem dos interesses corporativos da Instituição. Seu compromisso institucional e funcional é com a defesa do princípio da legalidade e, especialmente, do princípio da constitucionalidade, que significa que, no Estado Democrático de Direito, é a Constituição que dirige a marcha da sociedade e vincula, positiva e negativamente, os atos do poder público. Por isso, para além de sua função de representação judicial e extrajudicial da entidade pública em que se insere [...], deve contribuir também para (a) o aperfeiçoamento das instituições democráticas e, especificamente, para o aperfeiçoamento do Poder Judiciário; (b) a intocabilidade dos direitos fundamentais, especialmente dos direitos sociais; (c) a defesa da estabilidade dos funcionários contra o nepotismo que tem estado por trás da campanha contra essa garantia da função pública, pois ela é imprescindível não só como garantia de funções relevantes, mas também contra as nomeações políticas. ${ }^{19}$

\footnotetext{
${ }^{19}$ SILVA, op. cit., p. 606-607.
} 
9.8. Dentro dessas balizas, os advogados públicos, sejam estaduais ou municipais, exercem a essencial função de, independentemente do governante, defender interesses da coletividade, ligados ao interesse público, e interesses da administração na consecução de seus objetivos.

\section{Análise do caso concreto}

10. Assentadas essas premissas, aprecio a controvérsia proposta pela consulente.

10.1. Extreme de dúvidas que o art. 37, XI, da Carta da República, definiu limites de remuneração do funcionalismo público, estabelecendo um teto nacional, a significar que nenhum servidor público, de todas as esferas da Federação, poderá, a qualquer título, perceber quantia superior ao subsídio mensal de ministro do Supremo Tribunal Federal. Certo, ainda, que a Constituição definiu limites de remuneração tendo em conta cada unidade federativa (União, estados, Distrito Federal e municípios).

10.2. Assim, rememore-se: (i) na União, o teto de remuneração consiste no subsídio de ministro do Supremo Tribunal; (ii) nos estados e no Distrito Federal, os tetos foram definidos em função dos Poderes Executivo, Legislativo e Judiciário, estabelecendo-se como limite, respectivamente, os subsídios do governador, dos deputados e dos desembargadores, circunscritos estes a noventa inteiros e vinte e cinco centésimos por cento da maior remuneração mensal de ministro do Supremo; (iii) nos municípios, previu-se como teto o subsídio do prefeito.

10.3. Por último, a fixação do teto de remuneração para os integrantes das carreiras que desempenham "funções essenciais à Justiça": Ministério Público, Advocacia Pública e Defensoria Pública: o subsídio de desembargador. Indaga-se: esse diferenciado limite máximo de remuneração abrangeria os procuradores municipais?

10.4. A resposta há de ser positiva. Imaginar o contrário implicaria ignorar que a organização político-adminstrativa da República Federativa do Brasil compreende a União, os estados, o Distrito Federal e os municípios (C.F., art. 18). O entendimento discrepante neutralizaria os objetivos da Constituição, que elegeu a Advocacia Pública de todas as unidades da Federação (União, estados, Distrito Federal e municípios - CF, art. 18), titular de "função essencial à Justiça". Vale enfatizar que os advogados públicos municipais - os procuradores municipais - desempenham idênticas atribuições de 
seus congêneres da União, dos estados e do Distrito Federal, no contencioso judicial e na consultoria jurídica. O que se disse, relativamente a estes, aplicase, numa interpretação lógico-sistemática da Constituição, no tocante a eles, procuradores municipais.

10.5. Assim, exercendo funções "essenciais à Justiça", porque advogados públicos, os procuradores municipais são indispensáveis à consecução dos valores e princípios inscritos na Lei Maior, contribuindo, no âmbito da edilidade, para tornar realidade a dimensão igualitária da Justiça, indispensável à concretização do estado democrático de direito.

10.6. Admitir que os procuradores municipais não exercem essas fundamentais funções importaria descaracterizar o sistema de Justiça idealizado pela Lei Maior. E implica não reconhecer, tratando mal a Constituição, a natureza federativa do município, relegando-o a segundo plano.

10.7. Não há justificativa, portanto, no preconizar que os procuradores municipais não estão acobertados pela parte final do inciso XI do art. 37 da Carta da República, que estabelece como limite máximo de remuneração o subsídio de desembargador. Aliás, a ressalva contida na parte final do preceito - "aplicável esse limite aos membros do Ministério Público, aos Procuradores e aos Defensores Públicos" - , impõe ao intérprete, tendo em vista não ser possível distinguir onde a lei não distingue, considerar que a locução "aos Procuradores" alcança os advogados públicos da União, dos estados, do Distrito Federal e dos municípios.

10.8. Essa interpretação é a que resulta, linhas atrás foi dito, da interpretação lógico-sistemática da Constituição, que excepcionou, à vista de um objetivo transcendente e estrutural de toda a sua concepção ideológica, posta desde o preâmbulo, aqueles que desempenham "funções essenciais à Justiça", dos limites de remuneração do funcionalismo.

10.9. Pouco importa se isso redundar, na prática, na percepção de subsídios superiores aos do prefeito: essa circunstância, neutra para análise jurídica da questão, é reflexo da deliberada opção do legislador constituinte em privilegiar a construção de um estado democrático de direito, submetido ao império da lei. Convém anotar que a remuneração dos procuradores do Estado supera, de regra, o subsídio do governador.

10.10. Aplica maus tratos na Carta da República, não custa repetir, afirmar que os procuradores municipais não integram o rol de agentes que exercem "funções essenciais à Justiça", para o fim de submetê-los ao teto do subsídio do prefeito. Ora se os procuradores municipais desempenham "funções essenciais à Justiça", porque desempenham funções idênticas aos advogados 
públicos estaduais e federais, como não lhes outorgar uma das salvaguardas básicas deferidas aos seus congêneres estaduais e distritais? A discriminação seria perversa. E o direito não admite perversidades.

10.11. Convém invocar, no ponto, lição do procurador-geral do TCU, professor Lucas Rocha Furtado, a dizer que,

no âmbito dos Municípios nenhuma remuneração, subsídio, pensão etc. - à exceção do subsídio dos procuradores municipais - poderá ultrapassar o subsídio dos prefeitos [...] Aos membros do Ministério Público e aos defensores públicos estaduais, bem como aos procuradores estaduais ou municipais, o teto aplicável corresponde ao valor fixado como subsídio para os desembargadores estaduais. A rigor, em relação aos procuradores municipais, poder-se-ia indagar se o teto aplicável seria o subsídio dos prefeitos ou dos desembargadores. Em razão de o texto constitucional não ter feito qualquer menção ou distinção entre procuradores estaduais e municipais ("aplicável esse limite" - correspondente ao subsídio dos desembargadores - "aos membros do Ministério Público, aos Procuradores e aos Defensores Públicos"), parece-nos mais correto interpretar este trecho do citado inciso XI no sentido de que os procuradores municipais não se sujeitam ao subsídio dos prefeitos, mas ao dos desembargadores..$^{20}$

10.12. No mesmo sentido leciona Ivan Barbosa Rigolin: “Quisesse que apenas aos Procuradores e aos Defensores estaduais fosse deferido o teto dos Desembargadores, então precisaria tê-lo escrito com maior clareza e com todas as letras". ${ }^{21}$

10.13. Nos autos do RE 543.253/SP, que cuida do tema, da relatoria do ministro Celso de Mello - RE ainda não julgado - o parecer da ProcuradoriaGeral da República, lavrado pelo ilustre subprocurador-geral Edson Oliveira de Almeida, é também no mesmo sentido. Vale transcrever:

$[\ldots]$

6. Quanto ao inciso XI, do art. 37 da Constituição Federal, alterado pela

\footnotetext{
${ }^{20}$ FURTADO, Lucas Rocha. Curso de direito administrativo. Belo Horizonte: Fórum, 2007. p. 921922.

${ }^{21}$ RIGOLIN, Ivan Barbosa. O servidor público nas reformas constitucionais. Belo Horizonte: Fórum, 2008. p. $58-59$
} 
EC no 41/2003, percebe-se que foi estabelecido um subteto específico, aplicável aos membros do Ministério Público, aos Procuradores e aos Defensores Públicos. Então, a partir dessa delimitação, verifica-se que a melhor interpretação a ser feita é no sentido de que aos procuradores dos Municípios sejam assegurados a fixação do subteto da base tomada do subsídio mensal dos desembargadores dos Tribunais de Justiça (Poder Judiciário), conforme disposto no inciso XI do artigo 37 da Constituição. Pois, apesar de o dispositivo constitucional não conter explícita referência ao status dos procuradores municipais, não há uma interpretação mais coerente do que considerar Procurador como gênero, do qual tem como uma de suas espécies os Procuradores Municipais.

7. Portanto, defende-se a aplicação do subteto definido aos servidores públicos do Poder Executivo, determinando-se, contudo, que desse grupo se excluam os Procuradores Municipais, uma vez que o inciso XI, do artigo 37, da Constituição da República, prevê, de forma expressa, a aplicação do subteto específico aos Procuradores, dentre os quais se incluem os Procuradores Municipais.

8. Vale ressaltar o trecho do voto, da apelação em questão, do relator Rui Stoco, aduzindo que "emerge claro e icto oculi que os Procuradores em geral - como o são os autores - não se submetem ao subsídio de Prefeito como subteto ou limite. Pouco importa que sejam procuradores federais, estaduais ou municipais, pois onde a Magna Carta não distinguiu não cabe ao intérprete assim proceder. Não há como dar outra interpretação ao texto do inciso XI do art. 37 da Constitucional Federal. Aliás há absoluta coerência nessa simetria pois todos exercem seus cargos atuando perante o Poder Judiciário ou gravitam em torno dele (fls. 243).

$[\ldots]$

10.14. Cabe esclarecer que as específicas técnicas de interpretação constitucional deságuam na solução aqui preconizada. Luís Roberto Barroso registra que determinados preceitos, dentro de uma mesma estrutura normativa, podem desempenhar diferentes funções. Normas-princípio, com acentuado grau de abstração e destacada posição dentro do ordenamento, formuladas de maneira vaga e indeterminada, complementam e desenvolvem o sistema, não se limitando a particulares situações, concretizando-se, ao revés, em diversas hipóteses, e normas-disposição, com menor grau de abstração e restritas a específicas situações. 
10.15. O eminente constitucionalista realça que, embora não haja, entre as normas-princípio e as normas-disposição, hierarquia, posto incluídas no mesmo ordenamento, é certo caber aos princípios, "além de uma ação imediata, quando diretamente aplicáveis a determinada situação jurídica, uma outra, de natureza mediata, que é a de funcionar como critério de interpretação e integração do Texto Constitucional". ${ }^{22}$ Essas judiciosas observações demonstram o equívoco de se imprimir inteligência conducente à fixação do teto de remuneração dos procuradores municipais no subsídio do prefeito.

10.16. Com efeito, a elevação dos advogados públicos à condição de agentes públicos que desempenham "funções essenciais à Justiça" - deliberada opção constitucional para a concreção do estado democrático de direito - há de servir como critério de exegese e coerência, diante de sua indiscutível superioridade axiológica.

10.17. Assim, presente o postulado da unidade da Constituição - as normas constitucionais devem ser consideradas integradas num sistema coeso de princípios e regras, harmonizando-se aparentes antinomias - , não há dúvida que foi fixado um único limite de remuneração, o subsídio de desembargador, para os advogados públicos, vale dizer, para os procuradores estaduais, distritais e municipais, sob pena de desconsiderar-se a própria ideologia da Constituição, que é democrática e republicana e que, por isso mesmo, não admite ofensa injustificada ao princípio isonômico.

10.18. A harmonização do texto conduz o intérprete, necessariamente, a concluir que o teto de remuneração dos integrantes da Advocacia Pública dos estados, do Distrito Federal e dos municípios é o subsídio de desembargador. Idêntica conclusão é extraída dos postulados da máxima efetividade. Segundo esta, na interpretação das normas constitucionais é correto atribuir-lhes o sentido que lhes empreste maior eficácia. Do efeito integrador resulta que devem ser preferidas interpretações que possibilitem a integração política e social e o reforço da unidade política, finalidades precípuas da Constituição.

10.19. Ora, a interpretação coerente com a maior efetividade da norma constitucional e com a integração político-social da Carta da República, importa admitir que se objetivou destacar e salvaguardar as "funções essenciais

\footnotetext{
${ }^{22}$ BARROSO, Luis Roberto. Interpretação e aplicação da Constituição: fundamentos de uma dogmática constitucional transformadora. 7. ed. São Paulo: Saraiva, 2009. p. 155-156.
} 
à Justiça", parte da estrutura orgânica do Poder e intencional opção constituinte para a implementação do estado democrático de direito.

10.20. Esse conjunto de razões afasta interpretação no sentido de que teria a Constituição incorrido em omissão ao disciplinar o teto de remuneração dos advogados públicos dos municípios. E é pá de cal sobre a controvérsia a ressalva contida na parte final do inciso XI do art. 37, que não distingue entre procuradores estaduais e municipais.

10.21. Certo é que, mesmo que se admita existente a omissão, o que se diz ad argumentandum tantum, não poderia ela neutralizar a vontade da Constituição, que conferiu à atividade exercida pela Advocacia Pública a natureza de "função essencial à Justiça", para o fim de realizar a dimensão igualitária da Justiça, pilar do estado democrático de direito. Na verdade, a correta exegese da Carta da República resulta num único entendimento: o teto da remuneração dos procuradores municipais corresponde ao subsídio dos desembargadores.

\section{Conclusão: resposta à indagação}

11. Forte nas considerações expendidas, respondo à indagação formulada pela Associação Nacional dos Procuradores Municipais: a ressalva contida na parte final do inciso XI, do art. 37, da Constituição - " aplicável esse limite aos membros do Ministério Público, aos Procuradores e aos Defensores Públicos" - no que concerne "aos Procuradores", abrange os procuradores municipais. Onde a lei não distingue, não cumpre ao intérprete fazê-lo. Certo é que foi intencional a opção do legislador constituinte em excepcionar, dos limites de remuneração do funcionalismo em geral, os servidores que desempenham funções essenciais à consolidação do estado democrático de direito.

11.1. Assim, o teto de remuneração dos procuradores municipais, desde que admitidos por concurso público de provas e títulos e sejam servidores efetivos e estáveis, corresponde ao subsídio dos desembargadores, tal como ocorre com os seus congêneres dos estados e do Distrito Federal (C.F., art. 37, inciso XI, parte final).

É o parecer.

Brasília, 23 de junho de 2010.

Carlos Mário da Silva Velloso 


\section{Referências}

BANDEIRA DE MELLO, Celso Antônio. Curso de direito administrativo. 27. ed. São Paulo: Malheiros, 2010.

BARROSO, Luis Roberto. Interpretação e aplicação da Constituição: fundamentos de uma dogmática constitucional transformadora. 7. ed. São Paulo: Saraiva, 2009.

CIRNE LIMA, Rui. Princípios de direito administrativo. 7. ed. São Paulo: Malheiros, 2007.

FERREIRA, Sérgio de Andréa. Comentários à Constituição. Rio de Janeiro: Freitas Bastos, 1991. v. 3.

FURTADO, Lucas Rocha. Curso de direito administrativo. Belo Horizonte: Fórum, 2007.

MENDONÇA, José Vicente Santos de. A responsabilidade pessoal do parecerista público em quatro standards. Boletim de Direito Administrativo, v. 6, n. 26, p. 705-729, jun. 2010.

MOREIRA NETO, Diogo de Figueiredo. As funções essenciais à Justiça e as procuraturas constitucionais. Revista de Informação Legislativa, Brasília, ano 29, n. 116, p. 79-102, out./dez. 1992.

RIGOLIN, Ivan Barbosa. O servidor público nas reformas constitucionais. Belo Horizonte: Fórum, 2008.

SILVA, José Afonso da. Comentário contextual à Constituição. 5. ed. São Paulo: Malheiros, 2008. 